\title{
“A comunicação serve para que?”: Prof. Marques de Melo e sua trajetória de jornalismo comunitário, resistência civil e comunicação para o desenvolvimento ${ }^{1}$
}

"Communication is for what?": Prof. Marques de Melo and his trajectory of community journalism, civil resistance and communication for development

“La comunicación sirve para que?": Prof. Marques de Melo y su trayectoria de periodismo comunitario, resistencia civil y comunicación para el desarrollo

DOI: $10.1590 / 1809-58442018210$

\section{José Marques de Melo}

(Universidade Metodista de São Paulo, Escola de Comunicação, Educação e Humanidades, Programa de Pós-Graduação em Comunicação Social. São Paulo - SP, Brasil)

\section{Entrevista concedida a}

\section{Thomas Tufte ${ }^{1}$}

https://orcid.org/0000-0003-3253-8481

${ }^{1}$ (Loughborough University London, Here East Building, Institute for Media and Creative Industries. Londres, Reino Unido)

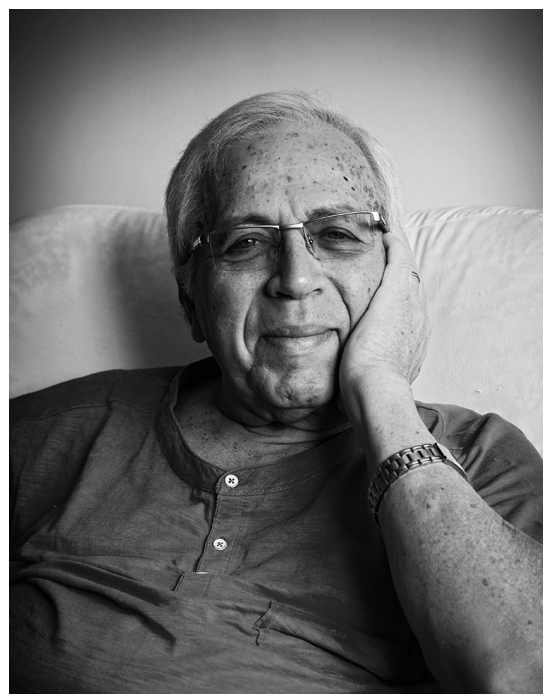

\section{TRAJETÓRIA}

Revista Intercom - Gostaria que você me contasse um pouco da sua trajetória...

José Marques de Melo - Eu comecei a carreira na comunicação como jornalista comunitário com uns 15 anos. Lá em Alagoas fui repórter da Gazeta de Alagoas, cobrindo a minha comunidade, Santana do Ipanema. As pautas eram aquelas coisas corriqueiras: casamento, eleição, velório... eu ia prestando atenção nos temas ligados a estagnação da comunidade. O pessoal fazia muita festa, muita comemoração e a escola estava caindo aos pedaços. Havia uma série de problemas ligados à economia, política etc. Essa orientação já era meu

1 Entrevista realizada em outubro de 2012. 
desejo de contribuir para a comunidade melhorar. Esse desejo veio da minha família, que é de classe média, e da influência que eu recebi na escola e na igreja. Eu fui vinculado aos movimentos católicos. Na adolescência, eu já pertencia à cruzada eucarística infantil, que fazia atividades comunitárias. Logo depois fui estudar em Maceió e no Recife e comecei a ler. Me defrontei com uma literatura que foi importante. O livro que mais me causou impacto foi $O$ caminho, de Octavio Brandão (2007). Era um proscrito de Alagoas, ele foi o primeiro divulgador das ideias marxistas na região. Eu li isso com uns 15 anos... já o primeiro livro sobre comunicação foi de Rui Barbosa (1990), A imprensa e o dever da verdade, que era de natureza ética. Nesse momento, vi que ser jornalista não é tão simples assim. Você tem que enfrentar as consequências. E o grande problema era a pressão que eu recebia para enviesar as informações. Teve uma notícia sobre uma família que era muito influente no município e quiseram me influenciar. Eu fugi desse controle porque eu queria ser fiel à verdade, queria procurar a verdade dos fatos.

Revista Intercom - O que você quer dizer com enfrentar as consequências de ser jornalista? Marques de Melo - Enfrentei várias consequências. Por exemplo, eu era católico, mas enfrentei imediatamente problemas com a igreja. Fui rejeitado pela comunidade católica porque eu escrevi um artigo contra a construção de igrejas. Eu defendia a tese de que nós tínhamos muitas igrejas e devíamos era fazer creches, hospital, fazer filantropia. Por que construir mais uma igreja? Na verdade, essa pressão da construção da igreja, só mais tarde é que eu fui perceber, era para combater o protestantismo. Onde tinha uma igreja protestante, eles criavam uma católica. Era intolerância religiosa. Minha mãe e meu pai me educaram de uma maneira mais tolerante. Eu sou na verdade de um gueto alagoano, porque meu pai era agnóstico. A influência católica veio mais das minhas tias, que eram carolas de igreja, bem tradicionalista. Meu pai era caixeiro viajante e passava pouco tempo conosco. Só quando eu já tinha uns dez anos de idade, ele passou a viver com a gente e montou um hotel.

Revista Intercom - Eu li que o hotel era a sua casa...

Marques de Melo - Exatamente, ele transformou nosso casarão no principal hotel da cidade. Então, papai me influenciou mais e houve uma ruptura familiar. Ele disse para minha mãe: "Eu não quero meus filhos homens educados pelos padres. As mulheres você pode mandar para o colégio das freiras, mas os homens não”. Ele me fez estudar em colégios evangélicos. Foi nesse contexto que eu fui criado, já com contradições na vida doméstica.

Revista Intercom - Aí surgiu seu desejo de se formar em jornalismo?

Marques de Melo - Sim. Tinha muita curiosidade de saber os fundamentos do jornalismo. Trabalhei na Gazeta de Alagoas e depois tive um upgrade no Jornal de Alagoas, o principal jornal do estado, a academia de Assis Chateaubriand. Lá eu aprendi a fazer tudo e depois 
me sentia vazio. Então, quis ir para Recife, eu queria fazer o curso de Jornalismo, mas não tinha ainda. Aí fui para Recife estudar Direito. Na verdade, toda a intelectualidade nordestina estudava Direito. Foi o momento também que me politizei, era o momento de grande efervescência com Cuba, Fidel Castro...

Revista Intercom - Quando você foi para Recife?

Marques de Melo - Foi em 1960, logo depois da Revolução Cubana. Comecei a ler essa literatura marxista e me engajei nos movimentos católicos comunistas de Recife. Eu lia tudo que me caia nas mãos. Lia demais. Tinha uma biblioteca pública na cidade que eu praticamente li tudo. Me politizei e participei do movimento estudantil. Foi um período meu de militância. Passei no vestibular de Direito, mas estavam criando o curso de Jornalismo naquela ocasião e também fui me inscrever no de Jornalismo. Fiz os dois ao mesmo tempo. Uma vida muito sacrificada. O curso de Direito eu fiz na universidade pública, onde não se pagava. Na Católica, onde tinha o curso de Jornalismo, tinha que pagar. Então, estava sendo criada a Superintendência para o Desenvolvimento do Nordeste - SUDENE e fui trabalhar lá.

\section{DESENVOLVIMENTO}

Revista Intercom - Essa etapa na SUDENE influenciou sua concepção de desenvolvimento? Marques de Melo - A SUDENE foi criada pelo governo de Juscelino Kubitschek e João Goulart. Como o Nordeste era um barril de pólvora, foi criada uma entidade capaz de minorar um pouco os conflitos. O diretor era Celso Furtado. Quando fiz concurso para SUDENE, estava entrando na universidade. Fui aprender administração pública para o desenvolvimento com os professores da Fundação Getúlio Vargas. Os mesmos que haviam treinado a equipe de Cuba, de Fidel Castro, para fazer o planejamento estatal... eles me prepararam para ser um administrador de planejamento. Vem daí minha capacidade de gestão. Tenho um curso completo de administração. Aprendi isso rapidamente e tive a sorte de trabalhar na assessoria técnica, diretamente com Celso Furtado. Mas minha noção primeira de desenvolvimento vem do jornalismo. Eu queria fazer comunicação para ajudar a resolver os problemas da minha comunidade. Foi com essa noção de desenvolvimento que percebi o desenvolvimento comunitário. Eu não faço essa separação entre comunicação para o desenvolvimento e comunicação. Não há comunicação para o não desenvolvimento. Comunicação é a essência do desenvolvimento. Sem liberdade, sem democracia não podemos ter progresso. Foi por aí que começou minha vinculação. Por isso, ao mesmo tempo que atuava na SUDENE, também participava dos movimentos de militância no Recife, numa entidade chamada Movimento de Cultura Popular (MCP). Eu tinha muita predileção pela cultura popular. 


\section{CULTURA POPULAR}

Revista Intercom - No Movimento de Cultura Popular você encontrou com Paulo Freire? Marques de Melo - No Movimento de Cultura Popular ele era um dos mentores. Foi lá que encontrei Paulo Freire, Abelardo da Hora, Germano Coelho... todo um conjunto de intelectuais de esquerda. O movimento de cultura popular era uma aliança entre católicos, evangélicos e comunistas. Essa frente lançou uma campanha de alfabetização de adultos que foi a chave para o Miguel Arraes ser eleito Prefeito do Recife graças à votação dos analfabetos pobres.

Revista Intercom - Isso foi antes do Golpe?

Marques de Melo - Sim, foi no final dos anos 1950 e início dos anos 1960. Ele foi eleito o prefeito de Recife e o Movimento de Cultura Popular era subsidiado pela prefeitura municipal. Tinha um vínculo muito estreito entre sociedade civil e governo municipal, porque sem Estado, nas regiões pobres, não se faz nada. A igreja era muito conservadora e ainda não estava engajada nisso. Miguel Arraes se elegeu governador muito jovem e não tinha conhecimento de gestão. Eu fui convidado para fazer parte da equipe de governo, no segundo ou terceiro escalão.

Revista Intercom - E com tantas atividades, tinham espaço e tempo para praticar o jornalismo também?

Marques de Melo - Tinha! Na verdade, eu fazia das tripas coração. Eu estudei Direito de manhã, Jornalismo à noite e trabalhava na SUDENE à tarde. Nos fins de semana fazia estágio no jornal. Foi instalado no Recife o jornal Última Hora Nordeste na cadeia de Samuel Vagner. E eu estagiava no jornal Última Hora nos fins de semana e férias. Tudo isso com uns 18, 20 anos. E fui guinado a uma posição chave no governo Arraes, eu era chefe do gabinete do secretário de educação de Miguel Arraes. O governo era todo de jovens. Eu fiquei como chefe de gabinete de Germano Coelho e aí eu aprendi um pouco da política por dentro. Mas depois de um ano fui trabalhar com o Movimento de Cultura Popular. Fui diretor administrativo do Movimento de Cultura Popular.

\section{Revista Intercom - Lá você atuou diretamente com o Paulo Freire?}

Marques de Melo - Essa questão é muito complicada. Em parceria com o governo João Goulart naquela ocasião, lançamos a grande campanha de alfabetização de adultos e fui o responsável pela implantação do sistema Paulo Freire no estado de Pernambuco. Quando o Movimento de Cultura Popular foi criado, ele contava com uma ampla aliança do partido comunista de diferentes facções e, inclusive, passando pelos católicos de esquerda, 
evangélicos progressistas, espíritas... o movimento era amplo. Paulo Freire estava testando o seu método de alfabetização de adultos lá. Mas havia discussão sobre como usar o método. Havia a intenção de usar o rádio. Já tinha a experiência do Movimento de Educação de Base (MEB), que era comandado por um bispo nordestino, Dom Eugenio Salles, lá no Rio Grande do Norte. Esse era outro método, que usava o rádio para educar em massa. E Paulo Freire não concordava com a educação massiva. Ele queria educação dialógica. O educador primeiro iria se educar com a comunidade, para depois educá-la. Uma coisa participativa. Houve um embate e o pessoal mais à esquerda, naquela ocasião, Partido Comunista e outros, queriam usar o rádio para rapidamente fazer eleitores. Em pouco tempo a pessoa se alfabetizava para poder votar... o método Paulo Freire demoraria muito mais tempo e ninguém sabia se daria para continuar o governo. Então, Paulo Freire ficou marginalizado e um pouco estigmatizado como uma pessoa de direita.

\section{Revista Intercom - Como Freire conseguiu implantar o método dialógico?}

Marques de Melo - Ele só conseguiu terminar o método dele com apoio da Aliança para o Progresso, com apoio do Governo dos EUA, que criaram a Aliança para o Progresso para jogar dinheiro e combater o comunismo em lugares como o Nordeste, um barril de pólvora. O próprio Bob Kennedy foi lá em Recife... Paulo Freire ficou magoado com o Movimento de Cultura Popular e se afastou do MCP. Foi dirigir o serviço de educação e extensão universitária da Universidade Federal de Pernambuco e ali ele continuou desenvolvendo o método, mas não tinha recursos suficientes. Então ele recebeu uma proposta do Secretário de Educação do Rio Grande do Norte, Calazans Fernandes, para aplicar o método na cidade de Angicos. Pela primeira vez usou o método de alfabetizar em 40 horas. Você tinha de passar por um processo de ir à comunidade, conhecer a comunidade, descobrir as palavraschaves do lugar. Aí que Paulo Freire foi ungido como grande educador. Paulo de Tarso, que era Ministro da Educação, o levou para Brasília para fazer uma grande campanha de alfabetização de adultos. Isso ainda antes do Golpe. Pernambuco era um dos poucos estados que não usava o método de Paulo Freire, porque estava usando o método da escola radiofônica, que era um método que politizava. Paulo Freire também se recusava a politizar. Ele queria, na verdade, conscientizar. Eram diferenças pedagógicas, mas ideológicas também. A rádio escola era o método dos bispos católicos, que foi inicialmente testada na Colômbia, na Rádio Sutatenza. A Conferência Nacional dos Bispos do Brasil pôs todas as rádios da igreja a serviço dessa alfabetização. Mas depois houve um acordo de Miguel Arraes como Ministro da Educação, para levar recursos federais para lá, mas a condição era aplicar o método Paulo Freire. Nós manejávamos os recursos e selecionávamos os professores e essa coisa toda. Foi uma coisa passageira, em 1963. 


\section{O GOLPE MILITAR}

Revista Intercom - Então, quando você estava nesse processo de educação popular houve o Golpe?

Marques de Melo - A própria alfabetização justificou muito o Golpe. Diziam que estavam preparando a revolução, que era um movimento subversivo... e veio o Golpe e tudo se interrompeu. Miguel Arraes foi preso e exilado e tudo aqui passou a ser banido. Eu não tinha me formado ainda. Me formei no final de 1964 em Jornalismo e no ano seguinte em Direito. Entre 1964 e 1965, fui perseguido, preso e respondi a vários inquéritos policiais militares. Luiz Beltrão, que era meu professor, me ajudou a me safar um pouco de Pernambuco. Ele me arrumou uma bolsa e fui pra Quito no Equador.

\section{REENCONTRO COM FREIRE}

Revista Intercom - Foi um momento de fuga em massa do Recife, não?

Marques de Melo - Todos tiveram de fugir. Em 1965, um parente da minha esposa foi obrigado a ir morar no Chile, para fugir da ditadura. Estava trabalhando na CEPAL e usei esse pretexto de ir visitar um parente. Lá, por coincidência, reencontrei Paulo Freire. Ele trabalhava no governo de Allende, na capacitação agrícola, e nos encontramos por acaso. Lá estavam muitos brasileiros. O Fernando Henrique Cardoso, o Serra, vários... um dia, o tio da minha esposa convidou, "vamos à feijoada da Dona Elza". Dona Elza era a mulher do Paulo Freire e todo sábado eles reuniam a "brasileirada" toda. Fui confraternizar e reencontrei Paulo Freire, ele muito abatido. Ele era muito amoroso, ligado à família, às raízes etc. $\mathrm{E}$ já tinha a certeza de que não iria voltar tão cedo. Ele me sentou no gabinete dele e me fez ler os originais do livro Educação como prática da liberdade (FREIRE, 1967). Li os originais do livro, pois ele me considerava como alguém que estava entre os comunistas e os católicos. Eu tinha na verdade trânsito pelas duas correntes, que era o perfil dele. Depois ele que se marxiza [sic] mais. O discurso do livro era revolucionário, mas não no sentido radical. Acho que depois, na Pedagogia do oprimido (FREIRE, 1987) que ele faz marxismo, aplica conceitos. Nesse ele estava mais na emoção do que na razão. O livro chave para entender Paulo Freire é Educação como prática da liberdade. Esse livro é mais importante do que Pedagogia do oprimido, porque é uma pedagogia da comunicação, por isso me identificava muito com ele.

\section{MATURIDADE TEÓRICA}

\section{Revista Intercom - Você foi para o Ciespal?}


Marques de Melo - Para fugir da ditadura eu fui para a CIESPAL. Foi lá que eu vi a literatura de Comunicação para o Desenvolvimento. Eu já havia farejado um pouco disso, porque um dos colaboradores do Movimento de Cultura Popular foi um sociólogo francês chamado Joffre Dumazedier. O Movimento de Cultura Popular foi inspirado no método Povo e Cultura da França. Desde lá do Recife a gente tinha uma série de projetos de alfabetização de crianças, de adultos e tínhamos as praças de cultura, onde nas praças dos bairros era instalado um aparelho de televisão e havia uma espécie de iniciação à recepção crítica da televisão. Esse pessoal era treinado pela equipe de Joffre Dumazedier, para fazer a leitura crítica da televisão. Então, há toda uma vinculação nesse processo com desenvolvimento nesse sentido. Fui para o CIESPAL em 1965. Lá encontrei Dumazedier e tomei conhecimento da literatura de Schramm, Lerner, Rogers. Na verdade, me fortaleci mais teoricamente no CIESPAL. Fiquei no CIESPAL por uns dois anos, passei um período lá e depois voltei e apresentei minhas duas teses. Fui um dos poucos latino-americanos que realmente conquistaram o título de pós-graduados em ciência da informação. Quando terminei com o CIESPAL, as coisas em Recife já tinham acalmado um pouco, mas a SUDENE tinha mudado completamente e eu me tornei uma espécie de pária.

\section{A VOLTA AO BRASIL}

\section{Revista Intercom - Como foi essa volta ao Brasil?}

Marques de Melo - Minha mulher estava grávida e ficamos em Recife esperando o nascimento de nossa primeira filha, que morreu, e logo em seguida viemos para São Paulo. Eu vim para São Paulo por duas razões: primeiro porque a Silvia estava muito abalada com a perda do bebê e o médico recomendou que saíssemos do ambiente. E em segundo lugar porque a perseguição era muito forte. Pernambuco foi um símbolo de resistência e foi onde teve a repressão mais dura, mas não era tão violenta porque como era um grupo que pertencia a um status social mais elevado, tinha um pouco mais de respeito.

\section{ECA}

Revista Intercom - Em São Paulo você fez parte da fundação da ECA?

Marques de Melo - Eu tinha 23 anos e a ECA não estava nem criada. Eu vim para São Paulo, na verdade, para sobreviver. Fiquei num dilema de trabalhar na Editora Abril e trabalhar numa agência de pesquisa de comunicação. Optei pela pesquisa e fui ganhar o dobro do que ganharia como jornalista. Em seguida, eu fiz concurso para ser professor na Escola de Comunicações e Artes, que acabava de ser criada. Fiz o primeiro concurso e fui aprovado. Éramos três professores de jornalismo. Os outros dois eram pessoas mais idosas e nenhum deles queria 
trabalhar em tempo integral. Eu, além de ser o mais titulado, tinha disponibilidade e fiz o que a Silvia chamava de voto de pobreza, porque eu fui ganhar na Universidade de São Paulo metade do que eu ganhava no mercado. Mas eu tinha vocação de professor...

\section{Revista Intercom - O senhor já tinha sido professor?}

Marques de Melo - O Beltrão foi meu professor e com ele aprendi a teoria do jornalismo. Era uma referência. Ele instalou o INCIFORM no Recife e foi o pioneiro do estudo científico da comunicação no Brasil. Ele foi catedrático no CIESPAL, deu aulas lá entre 1962 e 1963 sobre metodologia do ensino de jornalismo. Era uma metodologia muito questionada na época, mas ao mesmo tempo muito cobiçada. Como o Nordeste não tinha recursos para instalar uma escola de Jornalismo, não tínhamos nem sequer uma máquina de escrever no curso. Então, ele engendrou um método que se chamava Jornal Cobaia. Era uma coisa semelhante aos das escolas de Medicina. Nas escolas de Medicina, o aluno entra e recebe um cadáver para dissecar e trabalha quatro, cinco anos com aquele mesmo cadáver. Ele fez a mesma coisa, cada grupo recebia um jornal e mandava a gente dissecar e fazer as críticas. Nos fazia entrevistar os editores, os repórteres, os anunciantes, os leitores. Era um estudo para tentar entender. Depois a gente tinha de criar um novo jornal a partir dessa crítica. Não era só uma pesquisa de denúncia. Esse é um método típico de Beltrão, muito sintonizado com a comunicação para o desenvolvimento. Beltrão também me inspirou na área da cultura popular. Eu sempre tive predileção pela cultura popular. Desde a minha infância, eu lido com aqueles grupos folclóricos e tal. O Movimento de Cultura Popular em Recife valorizava muito a cultura popular, os grupos de frevo, pastoril, tudo isso era levado para uma praça para conviver, para lidar com a cultura do povo tal qual ela era. Esta postura era uma posição oposta a que a UNE adotou no Brasil, que nesse período queriam ideologizar a cultura popular. Eles organizaram grupos pelo país todinho, os CPCs, mas essa corrente usava a cultura popular de maneira instrumental. O nosso lá era uma convivência com a cultura popular. Eu frequentei muitas atividades e depois descobri Luiz Beltrão. Ele era um professor de jornalismo bem ortodoxo, um professor chato didaticamente, pois ele lia as suas aulas, era muito enfadonho. No começo eu desdenhava muito dele, mas depois tínhamos de prestar atenção na aula, pois não tinha literatura, tinha que prestar atenção nas aulas para poder fazer a prova.

\section{FOLKCOMUNICAÇÃO}

Marques de Melo - Em 1965, Beltrão publicou a primeira edição da revista Comunicações \& Problemas, lançando o manifesto da Folkcomunicação, em que o ex-voto é entendido como veículo jornalístico. Esse foi o primeiro trabalho dele e me marcou muito. Foi Luiz Beltrão que descobriu a relação entre o folclore e a comunicação. Em 1965 é o momento em que ele veio trabalhar em Brasília. Ele foi convidado pelo Presidente Castelo Branco, 
de quem foi amigo no Recife. O General Castelo Branco acompanhou o trabalho dele no curso de Jornalismo em Pernambuco e chamou ele para ir a Brasília para dirigir a faculdade de Comunicação. Naquela ocasião, quem não trabalhasse para os militares trabalhava onde? Eu o substituí nas aulas técnicas de jornalismo em Pernambuco, pois eu já vinha trabalhando como monitor, era uma espécie de estagiário de iniciação científica: fiz o meu primeiro trabalho sobre crônica policial na empresa do Recife, trabalhando com métodos quantitativos e qualitativos sob a supervisão dele, mas logo em seguida eu tive de vir para São Paulo. Ele me convidou para acompanhá-lo em Brasília, mas tivemos um rompimento. Eu disse a ele, “olha, eu sou contra esse governo, você está na verdade assistindo a esse governo. Eu não quero”. Ele ficou muito magoado e passou um ano sem se comunicar comigo. Reatamos depois que nasceu minha segunda filha. Depois ele também foi perseguido no governo de Costa e Silva, porque ele não era alinhado com os militares. Ele era representante dos jornalistas brasileiros nas conferências internacionais e percorreu o mundo inteiro, inclusive visitando os países chamados Cortina de Ferro e a China. Ficou muito impressionado com as mudanças que Mao Tsé-Tung estava fazendo lá. Quando mudou o governo ele foi afastado e demitido da Universidade de Brasília.

\section{Revista Intercom - Nesse período vocês reestabeleceram contato?}

Marques de Melo - Em 1967 ele já havia sido banido da Universidade de Brasília e o convidamos para a primeira conferência de abertura do ano letivo na ECA. Foi uma maneira que eu tive de prestigiá-lo. Eu era recém-formado e ao mesmo tempo também eu era na verdade uma espécie de exilado político, eu não revelei muito as minhas linhas porque havia muita perseguição. Então, entrei na USP. Fui nomeado chefe de departamento. Com 23 anos. Fiquei até 1972, neste ínterim. Eu, na verdade, fui descoberto primeiro pelos órgãos de segurança, porque eles passaram a ter computador, essas coisas todas que não tinham antes, então rastreavam tudo. Acharam meu passado e isso me comprometia. Em 1972, eu fui processado pelo Decreto Lei 477. O governo militar tinha vários instrumentos para punir. Na universidade, esse Decreto 477 punia professores e alunos. Quem fosse caracterizado como subversivo ficava proibido de trabalhar durante cinco anos e o estudante de estudar durante cinco anos. Eu fui condenado e ao mesmo tempo absolvido, uma coisa Kafkiana. Eles armaram um processo aqui em São Paulo, numa aula que eu dei técnica do lead. Essa aula técnica do lead era uma técnica americana.

\section{O SUBVERSIVO}

Revista Intercom - Isso foi caracterizado subversivo?

Marques de Melo - Foi, devido ao meu sistema de aula. Dou a aula teórica e em seguida faço a aplicação prática. Eu dei aula de como escrever o lead, diferentes tipologias etc. 
Depois eu fiz um trabalho prático. Pegava os jornais do dia e eles identificavam os tipos de leads. Todos os alunos de um modo geral recortavam os jornais, colocavam no papel e faziam uma espécie de apostila e essa apostila circulou muito na universidade. Teve várias edições e chegou até mesmo a circular fora porque o presidente da Organização Internacional do Jornalista difundia e publicava, traduzia para o francês, russo, árabe. Eu não sabia de nada disso. Mas os órgãos de repressão mapearam tudo isso e me acusaram de ser agente da construção da imagem negativa do Brasil no exterior. Eles diziam que eu denegria a imagem do governo brasileiro no exterior. Fui condenado como subversivo. Me proibiram de sair, de participar de conferências, durante muito tempo. A solução que encontrei foi pegar uma bolsa de estudos. Mas não queria bolsa americana para não me comprometer. Então, pedi uma bolsa aqui na Fundação de Amparo a Pesquisa do Estado de São Paulo e fui fazer o pós-doutorado. Eu sou o primeiro pós-doutor em Comunicação do Brasil que estudou no exterior. Fui para os EUA, passei um ano lá. Isso foi em 1973 e fui fazer um estudo sobre o sistema de pós-graduação em Jornalismo nos EUA. Quando eu voltei, a USP estava num período em que não havia mais vigência de lei no Brasil. Fui demitido sumariamente, uma cassação branca. Fiquei sem emprego e sem possibilidade de arrumar outro. Cheguei a lecionar em três ou quatro universidades particulares, mas uma semana depois me demitiam por causa dos órgãos de segurança que passaram por lá.

Revista Intercom - Apesar de você ter passado um ano fora?

Marques de Melo - Havia um contexto interno em que eles estavam desarticulando todos os movimentos de esquerda no Brasil. Era a linha dura do General Geisel, de extrema direita. Foi quando houve uma série de assassinatos e torturas, tudo isso. O relatório que fiz nos EUA desapareceu. Na ocasião, tudo que tinha minha assinatura foi banido do país. Me chamaram para ir a Moçambique ou voltar para os EUA, mas optei por ficar aqui. Queria ficar no Brasil.

Revista Intercom - O que aconteceu com a ECA nesses anos que você ficou fora da USP? Marques de Melo - Acabou muita coisa. Um dos crimes maiores foi a destruição do Museu da Imprensa. Foi queimado por uma das substitutas que eles contrataram, que era uma fascista italiana. Ela foi inspecionar o museu e abriu uma gaveta e viu jornais eslavos e fez a denúncia. Veio a ordem para queimar. Ela não observou que não eram só jornais eslavos. Foi Raymond Nixon que fez uma doação para a USP com exemplares de jornais diários de todo o mundo, do mesmo dia. Ela só viu os eslavos. Só se salvaram duas coleções, uma de quadrinhos e uma de cordel. 
JOSÉ MARQUES DE MELO

\section{COMUNICAÇÃO PARA O DESENVOLVIMENTO}

Revista Intercom - Como você conseguiu ficar no Brasil apesar de todas essas dificuldades? Marques de Melo - Recebi um convite de um amigo que é pastor metodista. "Aqui na Universidade Metodista nós estamos instalando agora uma faculdade de Comunicação e quero que você venha para cá. Você sabe muito bem que eu comungo das suas ideias”. Ele era do grupo Paulo Freire, era ecumênico e trabalhou com Miguel Arraes. Ele havia sido preso lá também. Três meses depois o serviço de segurança disse que eu não poderia dar aula lá. Mas o reitor foi austero, botou eles para fora. "Isso aqui é uma casa de Deus, quem manda somos nós da congregação e os senhores não vão mandar de fora”. Tinha pessoas assim no Brasil. O reitor tinha pulso. Teve coragem. Foi quando eu desenvolvi essa linha de Comunicação para o Desenvolvimento lá na Metodista. Fiquei lá até a Anistia em 1979, com a anistia política voltei para a USP.

Revista Intercom - Nos cinco anos que esteve na Metodista você trabalhou com Comunicação para o Desenvolvimento?

Marques de Melo - A linha que implantei na Metodista destoava da que predominava no país. Os estudos de Comunicação eram todos voltados para Indústria Cultural, os frankfurtianos. Haviam evidentemente estudos funcionalistas, da linha do Schramm, do Bergman, mas a maioria dos cursos de Comunicação usava a metodologia da pesquisa de denúncia, apesar da ditadura. A ditadura até estimulava essa crítica, pois havia uma revolta geral. As escolas de Comunicação se tornaram principal foco de resistência ao governo militar. Os outros cursos se acomodaram, todos, mas as escolas de Comunicação mantiveram uma resistência, uma discussão crítica muito forte, de denúncia. Nós resolvemos seguir na linha da contrainformação, mas para apresentar alternativas. O curso da Metodista estava comprometido com a comunicação alternativa, comunicação popular. Nós trouxemos Mattelart, Francisco Gutierrez que veio da Costa Rica, Jesús Martín-Barbero, Néstor Gárcia Canclini, essa turma todinha.

Revista Intercom - Você menciona em seus livros a Escola de Comunicação LatinoAmericana. É isso que está se conformando nessa época?

Marques de Melo - Consegui construir um espaço alternativo, foi quando veio um grande envolvimento com a América Latina. Era um projeto de internacionalização dos estudos de Comunicação no Brasil. Eu sempre defendi a tese de que ninguém pode ser provinciano, sem medir as consequências. Você tem de andar antenado com o mundo. O meu conceito da Escola de Comunicação Latino-Americana é que o CIESPAL na verdade é o lócus dessa escola dos anos 1960. Jorge Fernandez, fundador do CIESPAL, foi um grande estrategista e discutiu a 
relação entre Comunicação e Desenvolvimento. Eles adotaram uma linha, uma variante da teoria do Shramm e do Lerner que é a modernização. Não dava para ter desenvolvimento da comunicação sem desenvolvimento econômico, é preciso que as duas coisas venham ao mesmo tempo. Era uma nova proposta de como pensar no desenvolvimento.

\section{PENSAMENTO LATINO-AMERICANO DE COMUNICAÇÃO}

Marques de Melo - O pensamento latino-americano de comunicação é tecido no CIESPAL. Eles trouxeram especialistas do mundo inteiro, americanos, franceses, russos, italianos, belgas, espanhóis e eles deram o curso no CIESPAL. E essa geração que passou por lá absorveu tudo isso e depois foi gerando o pensamento latino-americano como pensamento mestiço. Foi um laboratório. Nós absorvíamos tudo aquilo e processávamos e daí saia a aplicação. Fugimos dessa falsa questão entre quantidade e qualidade, entre teoria crítica e teoria administrada e, na verdade, aproveitamos tudo.

Revista Intercom - A corrente latino-americana aplicava o pragmatismo?

Marques de Melo - Pragmatismo utópico é como se caracteriza o pensamento latino americano. As escolas europeias são mais contemplativas e os americanos eram muito voltadas só para a prática. As da América Latina queriam resolver o problema. Não é só desenvolver estudo de Comunicação. A comunicação serve para que? Quando vem a conexão entre o CIESPAL e CEPAL, a CIESPAL como parte de uma estratégia da UNESCO, para pré-dispor os meios de comunicação do mundo inteiro a apoiar os programas de desenvolvimento.

\section{Revista Intercom - Que latinos-americanos você lembraria?}

Marques de Melo - São vários latinos americanos, que o CIESPAL na verdade foi o laboratório dos mais jovens. Porque Beltrán, Bordenave, essa geração foi formada nos EUA. Eles estudaram agronomia, trabalharam no IINCA, OEA e foram fazer pós-graduação nos EUA. Eu diria que o típico pensador latino-americano que absorve tudo isso é Luis Ramiro Beltrán, um dos primeiros. Luis Ramiro foi discípulo do Rogers. E como bom latinoamericano ele contestava tudo, tanto que o Rogers modificou muito a teoria da difusão da inovação, ouvindo críticas de Luis Ramiro Beltrán. Tem também essa geração que veio posteriormente que passou pelo CIESPAL, uma quantidade enorme de pessoas. A minha geração é a segunda, formada nos anos 1970.

\section{INTERCOM}

Revista Intercom-E então, essa Escola de Comunicação Latino-Americana vaise configurando... 
Marques de Melo - Aqui no Brasil ela encontrou um espaço próprio para se difundir na Metodista. É um momento que a gente desenvolve uma série de estudos de comunicação alternativa, popular e participativa. Você vai encontrar uma certa confluência entre as ideias da Metodista e das ideias da Intercom. Nós criamos a Intercom em 1977, numa conjuntura em que a sociedade civil estava se rearticulando no Brasil. Era o governo de Geisel, não tinha espaço político para rearticular, mas se criava. Com a morte do jornalista Herzog aqui em São Paulo, ele foi professor da ECA, a contestação do regime militar começou. Isso em 1974, 1975. Os jornalistas se organizaram para denunciar e contestaram a farsa do suicídio. Em 1977, o congresso anual da Sociedade Brasileira para o Progresso da Ciência (SBPC), que reunia todos os cientistas do Brasil, foi proibido em Fortaleza. Cortaram todas as verbas e o congresso não pode ser realizado, pois não tinha subsídio e foi cancelado. O Cardeal Arcebispo de São Paulo, Dom Paulo Evaristo Arns, foi à televisão e disse "Não cancelem. Eu ofereço o espaço da PUC em São Paulo para vocês realizarem o congresso. Não tenho recursos, mas ofereço a solidariedade dos professores e alunos da PUC. Cada professor vai receber uma pessoa na sua casa e cada aluno vai receber uma ou duas pessoas”. O congresso se realizou nessa base. Esse congresso em São Paulo foi o que abriu as portas da ciência brasileira para as Ciências Sociais, ate então a ciência no Brasil era só Física, Química e Matemática, ciências duras, não tinha ciências sociais. Abriram espaço e logo tratou de ocupar o seu lugar. A Comunicação já vinha se desenvolvendo como área de ponta.

\section{Revista Intercom - A Comunicação já estava se institucionalizando?}

Marques de Melo - Inscrevemos a Comunicação como área de pesquisa. Nesse processo foram criadas as Sociedades de Sociologia, Antropologia, Política e assim por diante. Nós entramos nesse pulo da SBPC. Fiz uma consulta e havia na verdade um ambiente favorável para criar a de Comunicação. Isso foi em julho de 1977. Em dezembro, fiz a assembleia de fundação da Intercom na faculdade Cásper Líbero, eu também estava dando aulas lá. E foi lá que foi criada a Intercom. Só que dois meses depois o diretor da Cásper Líbero proibiu de usar o espaço. Ficou com medo e nós fomos abrigados pela Associação Brasileira de Imprensa (ABI). Foi assim o nascimento da Intercom. Na ABI, fazíamos o debate, e fizemos o primeiro congresso em Santos, em 1978. Foi semiclandestino. O Bispo de Santos nos aceitou na universidade católica, mas recomendou que os debates fossem realizados em outro espaço porque “era muito perigoso”. A abertura foi anunciada pelos jornais, mas o resto foi realizado em quartos de hotel, escondido mesmo. O primeiro congresso da Intercom foi preparado para ser um ato de insurgência contra o governo militar, algo que chamávamos de resistência civil.

\section{Revista Intercom - Porque tinha esse caráter?}

Marques de Melo - O governo decretava o currículo mínimo que todas as escolas no Brasil tinham que ter. Era uma coisa feita pelo Ministério, em Brasília. Não era só a lista 
das disciplinas, mas também o conteúdo das disciplinas. Estavam impondo tudo. Nós dissemos o seguinte, vamos obedecer desobedecendo. Mantemos a mesma nomenclatura e criávamos alternativa de conteúdo. Registrávamos nas cadernetas do mesmo jeito que o MEC queria, mas o conteúdo era outro. Eles sabiam que era um congresso de resistência civil. Fizemos propostas curriculares que foram aceitas pela grande maioria das escolas, mas as mais conservadoras tiveram a sua posição. Isto foi publicado no livro Ideologia no Poder do Ensino de Comunicação (MELO; FADUL; SILVA, 1979) que é o primeiro livro dos anais da Intercom. Foi um best-seller. Ele circulou o país inteiro e era o manual para aplicar o currículo do MEC com o conteúdo alternativo. O segundo congresso que nós fizemos foi Comunicação e Classe Subalterna. Nenhuma faculdade queria sediar. Fizemos numa chácara da Igreja Metodista em São Paulo. Os congressos eram pequenos, tinham 50, 100 pessoas no máximo. O terceiro foi Populismo e Comunicação, esse foi feito numa casa de freiras lá em Itapecerica da Serra, e o quarto foi Teoria e Pesquisa em Comunicação - Panorama Latino Americano. Até aqui não havia participação estrangeira. Fizemos a opção de congressos de baixo perfil, sobretudo, para evitar o que nós chamamos de corrupção. Era para evitar a participação dos estrangeiros. Franceses, americanos... eles queriam cooperar, mas, na verdade, queriam impor seus pontos de vista. Nós queríamos ter independência.

Revista Intercom - E a década de 1980, como você poderia caracterizar esse período? Você voltou para a ECA. Foi um período de reconstrução?

Marques de Melo - Com a anistia, voltei para ECA e tive que reconstruir minha carreira toda lá, uma coisa muito tortuosa. Eu tive que voltar a me submeter a um concurso de livre docência, isso em 1983, dez anos depois do doutorado. Mas já em 1987 recebi o título de professor titular e quis dar uma respirada. Pedi uma bolsa ao CNPq para um pós-doutorado na Espanha.

\section{Revista Intercom - Em Madri?}

Marques de Melo - Sim. Mas não cheguei a ficar os dois anos... no meio de caminho fui chamado pela USP para me candidatar a diretor da ECA. Assumi em 1989 e me candidatei e fui indicado na lista tríplice como primeiro lugar. Foi a primeira vez que na ECA que um candidato apresentou uma plataforma de trabalho.

\section{TELENOVELAS}

Revista Intercom - Você criou um núcleo de estudo de pesquisas sobre telenovelas?

Marques de Melo - Quando eu cheguei na ECA em 1989, fiquei muito espantado pelo fato de não se pesquisar televisão de massa. Eu havia feito a primeira pesquisa sobre telenovelas 
no Brasil, em 1967, quando eu ainda estava dando aula na Cásper Líbero e essa pesquisa foi muito mal recebida. Disseram que eu estava pesquisando lixo e o trabalho foi execrado. Eu tinha feito quatro pesquisas com meus alunos. Uma sobre telenovelas, outra sobre Histórias em Quadrinhos, sobre a imprensa de imigrantes estrangeiros e outra sobre a imprensa diária de São Paulo. A única que teve certa aceitação foi sobre a imprensa diária de São Paulo. A imprensa de imigrantes estrangeiros eu nunca publiquei e desapareceu, o material foi reencontrado recentemente. Publiquei os de quadrinhos e de telenovelas. A pesquisa de telenovelas partia do pressuposto de que a telenovela era um programa para mulheres e eu tinha premunição de que não era bem verdade. Você fazia a entrevista nas residências e perguntava: “Quem vê telenovela?” Respondiam “minha mãe”, “minha sogra” e os homens camuflavam. Então, resolvi fazer um teste projetivo. Exibia várias imagens e perguntava quem se identifica com quem... ou - “Ontem, quem estava assistindo telenovela na sua casa?” Estava o marido, o sogro, o filho. Toda a família via a telenovela. Porque na verdade, em 1967, o país estava em pleno regime militar e as atividades políticas foram coibidas. Os homens que não podiam ir para rua fazer política. Era perigoso até ir para o bar e conversar sobre política. As mulheres faziam questão de conservar os homens dentro de casa para evitar problemas maiores. O que eles iriam fazer? Naquela hora só tinha telenovela, então eles começaram a assistir telenovelas e se aficcionaram.

Revista Intercom - Por que você optou em criar esse núcleo de pesquisa em 1989?

Marques de Melo - Quando eu assumi a direção da ECA, constatei que o curso de Rádio e Televisão não mencionava telenovela. O tema estava ausente completamente. O maior mercado hoje no Brasil é produção de telenovela, na Globo, na Bandeirantes, em todas as emissoras. Resolvi criar o núcleo e na ocasião poucos professores se dispuseram a participar. Havia uma resistência e Anamaria Fadul foi uma das poucas que aceitou. Eu busquei os recursos, bati em todas as portas e foram negados os recursos para pesquisa. Mas consegui um apoio com a Fundação Rockefeller e instalamos o núcleo de documentação da memória da telenovela no Brasil. Esse interesse dos estrangeiros favoreceu muito para que os brasileiros se animassem pelo assunto. Porque aqui no Brasil é o seguinte: se os estrangeiros estão estudando deve ser uma coisa interessante. Mattelart e Michele estiveram aqui e fizeram o estudo sobre o carnaval das imagens. Outros quatro ou cinco estrangeiros passaram por aqui, então começou a ser cogitado pelos brasileiros estudar novelas...

Revista Intercom - Mas as agências de financiamento não abriram recurso?

Marques de Melo - Demorou muito. Então eu fui à Globo e consegui o apoio deles, pelo menos para ter acesso ao material. No começo foi muito difícil, porque eles tinham uma resistência muito grande aos acadêmicos. Hoje em dia existe uma excelente relação. Já comemoramos mais de 20 anos de criação do núcleo de telenovelas. 
Revista Intercom - Mas alguns anos depois o fogo queimou...

Marques de Melo - Para você ver como é um objeto tão maldito na academia. O fogo destruiu tudo que tinha. Ainda hoje não se sabe o que causou. É um mistério. O que me disseram é que, estranhamente o núcleo da novela, estava no mesmo andar na mesma posição da tesouraria da Escola, acho que queriam atingir as duas coisas.

\section{CÁTEDRA UNESCO DE COMUNICAÇÃO}

Revista Intercom - Nessa época que você começa a cátedra da UNESCO?

Marques de Melo - Fui para Barcelona em 1991 e 1992. A cátedra foi aberta lá. Elizabeth Fox foi a primeira. Me chamaram em seguida para ficar quatro meses. Para mim era conveniente porque eu ia terminando a minha gestão na ECA. Precisava desacelerar um pouco e terminei passando quase um ano lá. Era período das olimpíadas de Barcelona e fui integrar um júri da inovação para as Olimpíadas Culturais. Foi um dos períodos mais intensos de trabalho. Porque eu tive que dirigir a cátedra da UNESCO, acabei fazendo um pós-doutorado e iniciei vários projetos simultâneos. Criei essas redes todas como a Folkcom, Eclesiocom, Politicom, Comunicom Saúde.

Revista Intercom - Depois disso veio a ideia de criar uma cátedra com base nessa experiência? Marques de Melo - Foi na verdade uma decisão do diretor de comunicação da UNESCO. No caso da Comunicação eles quiseram induzir cátedras na área e acharam que valeria convidar e induzir pessoas a pensar algo diferenciado. Convidaram um grupo de pelo menos dez pessoas para assumir a cátedra. Eu estava me aposentando na USP. Eles insistiram que o convite era pessoal e eu seguiria trabalhando na Universidade Metodista de São Paulo. Consultei o reitor, que foi muito receptivo e demos entrada nos papéis todos. A cátedra existe até hoje, com perfil de desenvolvimento regional, muito vinculado com comunicação para o desenvolvimento. No começo pensamos que a cátedra seria co-financiada pelas empresas do grande $\mathrm{ABC}$, mas as negociações não deram certo. Eu não aceitava que o projeto fosse tutelado. A universidade pôs recursos, porque deu prestígio à universidade. Fiz um programa de trabalho que tivesse pesquisa, documentação, extensão e eventualmente ensino. Começamos a realizar cursos, o primeiro curso de Comunicação para o Desenvolvimento Regional e trouxemos cinco professores. Hoje já tem uma revista, a Comunicação e Sociedade. Também tem uma revista eletrônica, o JBCC e o Pensamento Comunicacional Latino Americano, que transformamos em uma enciclopédia.

Revista Intercom - Como está o tema da Comunicação para o Desenvolvimento no Brasil hoje? 
Marques de Melo - Estamos fazendo parte de um grupo de trabalho junto ao Governo Federal para impulsar o tema. Acabamos de fazer quatro publicações com o IPEA. É uma coisa de influenciar os gestores mesmo, é como lobby. Mas para valorizar a comunicação para o desenvolvimento, é preciso entender que a comunicação é instrumento de desenvolvimento. Ao mesmo tempo temos que sensibilizar as universidades para a questão do desenvolvimento. O grande problema da nossa área de Comunicação é que cresceu muito, mas está na verdade ao Deus dará. Não tem muito compromisso com a transformação do país. O que tem crescido muito é o ensino da comunicação social nas universidades. A Comunicação para o Desenvolvimento é a essência da Comunicação. O crescimento de uma institucionalização de Comunicação para o Desenvolvimento como campo, como o mestrado, só está sendo retomado agora.

\section{Referências}

BARBOSA, R. A imprensa e o dever da verdade. São Paulo: Com-Arte; Editora da Universidade de São Paulo, 1990.

BRANDÃO, O. O Caminho. Alagoas: Edufal, 2007.

FREIRE, P. Educação como Prática da Liberdade. Rio de Janeiro: Paz e Terra, 1967.

Pedagogia do oprimido. Rio de Janeiro: Paz e Terra, 1987.

MELO, J. M. ; FADUL, A. ; SILVA, C. E. L. Ideologia e poder no ensino de comunicação. São Paulo : Cortez e Moraes, Intercom, 1979.

\section{Thomas Tufte}

Professor e Diretor do Institute for Media and Creative Industries, da Loughborough University London, desde 2018. Pesquisador Sênior Associado da Universidade de Joanesburgo, desde 2013. Foi Diretor de Pesquisa na School of Media and Sociology, da Universidade de Leicester (20162018) e professor de Comunicação na Universidade de Roskilde (2004-2012). Possui mestrado em Sociologia Cultural (1989) e Doutorado em Comunicação (1995). E-mail: t.tufte@lboro.ac.uk.

Recebido em: 27.06.2018

Aceito em: 08.11.2018 